\title{
FIGURATIVE MEANING IN CULTURAL LEXIS: A CASE STUDY ${ }^{1}$
}

\author{
Isabel Negro Alousque 2
}

\begin{abstract}
The relationship between language and culture has been a postulate of modern linguistics since the Sapir-Whorfian hypotheses. Such connection is particularly noticeable in lexis. The purpose of this article is to study the lexis belonging to cultural domains through the analysis of the English vocabulary from the domain of the weather and to examine the figurative meaning of the lexical units from this domain.

Key words: Cultural domain, lexical unit, idiom, figurative meaning, connotation.

El significado figurado en el léxico cultural: Análisis de un campo léxico

Resumen: La relación entre lengua y cultura es uno de los postulados de la lingüística moderna desde la teoría de Sapir-Whorf. Esta relación se manifiesta especialmente en el léxico. El objetivo del presente artículo es estudiar el léxico perteneciente a dominios culturales) a través del análisis del vocabulario asociado al dominio del clima en la lengua inglesa, y examinar el uso figurado de las unidades léxicas de dicho dominio.

Palabras clave: Dominio cultural, unidad léxica, expresión idiomática, sentido figurado, connotación.
\end{abstract}

\section{INTRODUCTION}

Language constitutes the most distinctive feature of a culture. Such relationship is particularly seen in the lexicon. As Wierzbicka (2008: 7) points out: "[...] the meanings of words provide the best evidence for the reality of cultures as ways of living, speaking, thinking and feeling which are widely shared in a particular society."

The cultural component of the lexis has been shown by a number of authors (Inchaurralde 2003; Wierzbicka 1992, 1996, 1997, 1999). Wierzbicka claims that most words are cultural artifacts, reflecting aspects of the cultures in which they were created. Inchaurralde (2003: 179) postulates that certain lexical units are associated with cultural lexical scripts, which are in turn linked to a certain cultural background. It is the case of the domain of bullfighting in the Spanish language.

The significance of culture for figurative language has been the subject of much recent research. Boers and Stengers (2008) state that idiom clusters are determined by the relative salience of certain domains in a given community. In this sense, they remark (2008: 64): "Some experiential domains may be quite culture-specific and consequently their derived idioms may be quite language-specific".

Date of reception: June 2009.

Date of acceptance and final version: September 2009.

2 Assistant teacher, Departamento de Filología Inglesa I, Universidad Complutense; $\square$ inegro@ccee.ucm.es. 
Dobrovol'skij and Piirainen (2005) have described the different types of cultural phenomena underlying conventional figurative units. The issue of the cultural basis of conceptual metaphor has also been undertaken by Gibbs and Stern (1999), Kövecses (2000, 2006), Mussolf (2004), Quinn (1991), and Quinn and Holland (1987). Kövecses has explored metaphor variation across and within cultures, and has focused on cross-cultural similarity and variation in the conceptualization of emotion. Quinn and Holland have studied the culture specifics of proverbs (1987).

Culturally marked lexis is linked to cultural domains. In the present article I focus on the weather domain. Little research has been done on the culture-specific features of this domain. Only is it mentioned by Boers and Stengers (2008) in their investigation on the composition of idiom repertoires in English, Dutch and Spanish.

\section{THE WEATHER DOMAIN IN THE ENGLISH LANGUAGE}

I chose the weather domain with its associated lexical field because it is a very basic and frequent topic. The data for analysis were derived from two English dictionaries, the Oxford Dictionary of English Idioms (1993) and the Longman Dictionary of Contemporary English (2009). The search through the dictionaries generated 44 words and phrasal verbs and 70 idioms, and was complemented with corpus data from Financial Times.

The claim about the cultural salience of the weather domain in English is supported by the following facts:

1. First, the weather is a very popular conversation topic. Talking about the weather is a near obsession in Britain because it is notoriously variable and unpredictable. As Mikes (1970: 20) remarks: "This is the most important topic in the land. In England this is an ever interesting topic, and you must be good at discussing the weather." He even suggests some statements about the weather that people make in a conversation:

\section{Lovely / Nasty day, isn't it? Wonderful, isn't it? \\ Isn't it beautiful / dreadful?}

Similarly, it is common to say How do you like this weather? when greeting somebody.

2. Weather lexical items can be applied through meaning extension to other domains like the economy and feeling. In Lakoff's (2006) terms, weather metaphors would involve a conceptual mapping (i.e. a fixed pattern of conceptual correspondences) from a concrete domain (the source domain, WEATHER here) to an abstract domain (ECONOMY, FEELING).

The idea that weather metaphors are an important means of conceptualizing economic problems is illustrated through the following examples from Financial Times:

The inflationary cloud has a silver lining for profits. (9 February 2009)

Cargill feels the chill of economic downturn. (15 April 2009)

Brown to Bank: lighten up. (22 May 2009) 
When a financial storm struck Wall Street, traders sought shelter in the dollar.

(22 May 2009)

Rising debt clouds market optimism. (23 May 2009).

View of the Day: Sterling still faces headwinds. (15 July 2009)

While business headlines in the rest of the world speak of clearing skies and rays of sunshine, the Baltic states are still in the midst of a howling economic gale.

(3 August 2009)

End to pay freeze policy foreseen. (11 September 2009)

The heavy presence of weather metaphors in business discourse seems to corroborate the relevance of this domain. The use of weather expressions to describe a feeling will be examined in the next section. The linguistic salience of the domain of the weather is highlighted by two facts: a) the lexical richness of the domain, and b) the figurative use of a wide range of words from the domain.

Weather items are abundant in the English lexicon. Table 1 provides a sample:

\begin{tabular}{|l|l|}
\hline HEAT / COLD & $\begin{array}{l}\text { freezing, mild, warm, hot, boiling } \\
\text { warm up, cool down }\end{array}$ \\
\hline RAIN / SNOW & $\begin{array}{l}\text { shower, downpour, drizzle, deluge, sleet, slush } \\
\text { rainy, wet, damp, humid }\end{array}$ \\
\hline WIND & breeze, gust, bluster, gale \\
\hline CLEAR/DARK DAY & $\begin{array}{l}\text { bright, cloudy, overcast, bleak, dreary } \\
\text { brighten up, cloud over }\end{array}$ \\
\hline
\end{tabular}

Table 1. Weather lexical items in the English language.

The number of adjectives expressing different degrees of heat or cold is particularly striking. Their meaning is best illustrated on a scale such as the following:

\begin{tabular}{|l|l|}
\hline COLD + & icy / arctic / bitter (extremely cold) freezing / \\
& frosty (very cold) \\
& chilly (quite cold) \\
& cold, raw (cold and wet) \\
& mild \\
& warm, muggy (unpleasantly warm) \\
& hot, baking (unpleasantly hot) \\
& boiling, sweltering (very hot) \\
HEAT_ & scorching (extremely hot) \\
\hline
\end{tabular}

We also find several pairs of synonymous terms (mostly adjectives): bright/clear, cloudy/ overcast, rainy/wet, damp/humid, shower/downpour.

Further, in line with the common belief that the British climate is rainy, we encounter a few words denoting various kinds of rain:

Shower / downpour: a short period of heavy rain. 
Deluge: a long period of heavy rain.

Drizzle: a period of light rain.

Sleet: a mixture of rain and snow.

Finally, a set of words describe different types of wind:

Breeze: light wind.

Gust: sudden strong wind.

Gale: very strong wind.

Bluster: wind blowing in short but strong and frequent bursts.

The set of phrasal verbs connected with the weather (warm up, cool down, cool off, freeze over, chill out, brighten up ...) adds to the richness of the domain in English. The relevance of weather-related vocabulary in English is confirmed by the fact that many words from this domain give rise to figurative expressions. In this light, Boers' and Stengers' (2008: 63-78) study of English idioms reveals that the weather is one of the source domains represented in the repertoire of frequently used English idioms. In their view, lexical salience and cultural salience are interrelated.

By means of illustration consider the following figurative expressions derived from the weather domain:

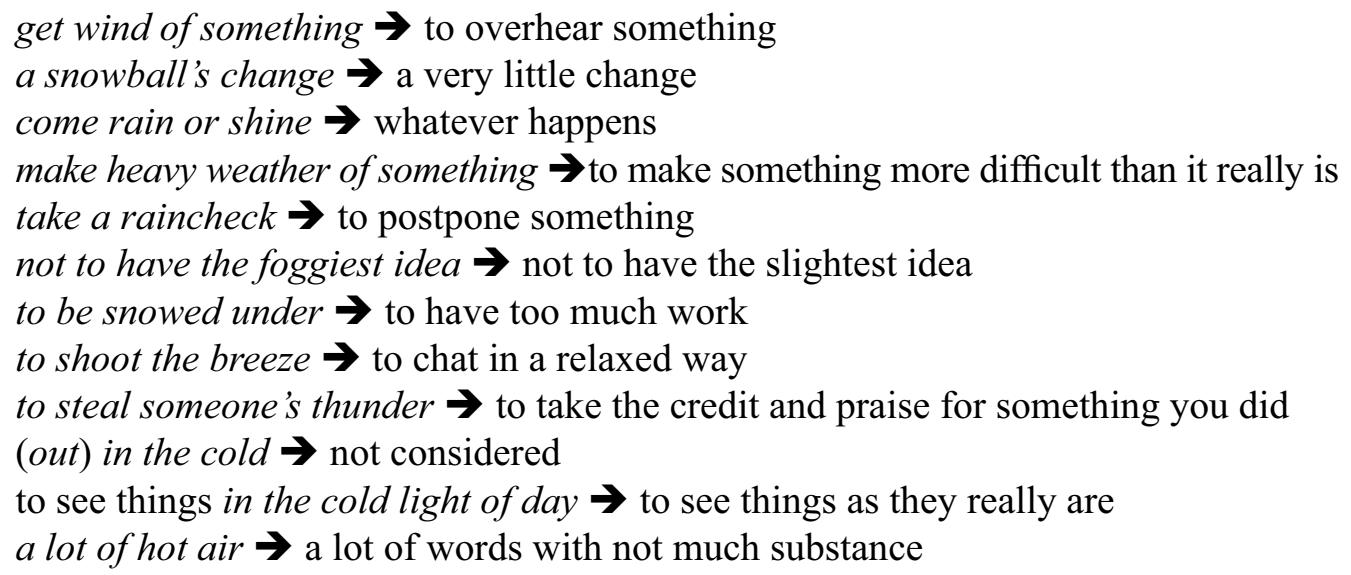

The range of figurative meanings of the adjective hot is particularly noticeable:

\begin{tabular}{|l|l|}
\hline Meaning & Expression \\
\hline Passionate & hot-blooded \\
\hline Angry & hot-tempered \\
\hline Popular & hot property \\
\hline Difficult & a hot potato \\
\hline Recent & hot off the press \\
\hline Spicy & hot curry/chili \\
\hline
\end{tabular}

Table 2. Figurative meanings of the adjective hot.

In the next section we proceed to the analysis of the figurative expressions from the English domain of the weather. 


\section{ANALYSIS OF ENGLISH WEATHER-BASED FIGURATIVE EXPRESSIONS}

We suggest classifying the weather expressions according to the meaning they convey. We have found three categories of figurative expressions:

1. Expressions which describe somebody's physical or emotional state

2. Expressions which describe somebody's way of acting or behaving

3. Expressions which describe a feeling.

The expressions that describe somebody's physical or emotional state are shown in table 3:

\begin{tabular}{|l|l|l|}
\hline State & Description of the state & Figurative expression \\
\hline Physical state & Illness & to feel under the weather \\
\hline & Drunkenness & to be seven sheets to the wind \\
\hline Emotional state & Confusion/unawareness & to be in a fog \\
\hline
\end{tabular}

Table 3. Weather idioms that describe a physical/emotional state

A greater proportion of idioms describe someone's way of acting or behaving. They are given in table 4:

\begin{tabular}{|l|l|l|}
\hline Behaviour pattern & Metaphorical expression & Meaning \\
\hline Caution & $\begin{array}{l}\text { to know which way the wind blows } \\
\text { to see which way the wind blows }\end{array}$ & $\begin{array}{l}\text { know/see how things are devel- } \\
\text { oping and be prepared for the } \\
\text { future }\end{array}$ \\
\hline Boldness & $\begin{array}{l}\text { sail close to the wind } \\
\text { throw caution to the wind }\end{array}$ & take risks \\
\hline Volatility & to blow hot and cold & keep changing your attitude \\
\hline Optimism & to look on the bright side of life & be positive \\
\hline Idealism & $\begin{array}{l}\text { to be chasing rainbows } \\
\text { to have your head in the clouds }\end{array}$ & $\begin{array}{l}\text { try to get something unattain- } \\
\text { able } \\
\text { be unrealistic }\end{array}$ \\
\hline Exaggeration & a storm in a teacup & $\begin{array}{l}\text { make a fuss about sth unimport- } \\
\text { ant }\end{array}$ \\
\hline Criticism & to pour cold water on something & $\begin{array}{l}\text { spoil someone's plan by criti- } \\
\text { cizing them }\end{array}$ \\
\hline Causing fear & to put the wind up somebody & frighten somebody \\
\hline Disloyalty & a fair-weather friend & $\begin{array}{l}\text { a friend who is there only when } \\
\text { times are good }\end{array}$ \\
\hline
\end{tabular}

Table 4. Weather idioms that describe somebody's way of acting or behaving.

A small number of idioms describe someone's behaviour in a given situation. They are provided in table 5: 


\begin{tabular}{|l|l|}
\hline Situation & Idiom \\
\hline Going through a hard time & hit rough weather \\
\hline Managing in a difficult situation & to weather the storm \\
\hline Lacking help / support & to be twisting in the wind \\
\hline $\begin{array}{l}\text { Acting without thinking about the conse- } \\
\text { quences }\end{array}$ & to do something in the heat of the moment \\
\hline
\end{tabular}

Table 5. Weather idioms that describe somebody's behaviour in a given situation.

It must be noted that the word weather has a positive meaning when it functions as a verb (to weather the storm), whereas it carries a negative connotation when it is a noun (to hit rough weather).

Some weather expressions refer to events that are likely to happen in the future: into each life some rain must fall, be quiet before the storm; the lull before the storm; a cloud on the horizon; to save money for a rainy day. This might be accounted for in grammatical terms. Indeed when we talk about the weather, we often make predictions about the weather in the near future. Weather figurative expressions are thus used to refer to possible future facts.

What is most noticeable is that in these expressions the future is regarded as a time when difficulties or problems will arise. There is one single idiom (to wait for a raindrop in the drought) where the future event is something pleasant, yet unlikely to happen, which corroborates the negative value of the bulk of weather expressions. Such negative connotation results from the negative meaning of the nuclear word. Table 6 groups the expressions negatively valued according to their meaning:

\begin{tabular}{|l|l|}
\hline Meaning & Weather idiom \\
\hline Having difficulties/problems/unpleasant experiences in & $\begin{array}{l}\text { to hit rough weather } \\
\text { to get into hot water } \\
\text { Into each life some rain must fall } \\
\text { It never rains but it pours } \\
\text { to be in the quiet before the storm } \\
\text { a cloud on the horizon } \\
\text { the lull before the storm } \\
\text { to save money for a rainy day }\end{array}$ \\
\hline Wrong action & $\begin{array}{l}\text { to rain on your parade } \\
\text { to be under a cloud }\end{array}$ \\
\hline
\end{tabular}

Table 6. Weather expressions with a negative meaning.

Very few weather expressions carry a positive connotation: a ray of sunshine (something which brings you happiness), to weather a storm, to be on cloud nine, to be as right as rain, to be home and dry (be safe and successful after a struggle to achieve something).

A considerable fraction of weather lexical units reflect a metaphorical transfer to the domain of FEELING, as illustrated in table 7: 


\begin{tabular}{|l|l|}
\hline Idiom & Meaning \\
\hline $\begin{array}{l}\text { to give somebody a warm welcome/reception } \\
\text { to warm to somebody }\end{array}$ & Friendliness \\
\hline $\begin{array}{l}\text { to give somebody a cold/ frosty welcome/recep- } \\
\text { tion }\end{array}$ & Unfriendliness \\
\hline $\begin{array}{l}\text { a heated discourse } \\
\text { hot-blooded }\end{array}$ & Passion \\
\hline $\begin{array}{l}\text { to do something in cold blood } \\
\text { cold-blooded, cold-hearted } \\
\text { to cool a relationship } \\
\text { to leave somebody cool }\end{array}$ & Indifference \\
\hline to get cold feet & Fear \\
\hline $\begin{array}{l}\text { stormy } \\
\text { to storm } \\
\text { hot-tempered } \\
\text { to get hot under the collar } \\
\text { to have a face like thunder }\end{array}$ & Anger \\
\hline $\begin{array}{l}\text { to chill out, to keep cool } \\
\text { to breeze }\end{array}$ & Calmness \\
\hline $\begin{array}{l}\text { to be on cloud nine } \\
\text { to brighten up }\end{array}$ & Happiness \\
\hline hazy & Confusion \\
\hline
\end{tabular}

Table 7. Weather expressions used to describe a feeling.

The idioms give somebody a warm welcome/reception and its negative counterpart, To give somebody a cold/frosty welcome/reception, are instantiations of the conceptual metaphor LOVE IS HEAT (Lakoff \& Johnson 1980).

The range of weather figurative expressions also shows in their form. We find the following types of lexical unit:

- Idioms: be home and dry, feel under the weather, be on cloud nine, shoot the bree$z e$.

- Proverbs: Every cloud has a silver lining, It never rains but it pours.

- Formulas: come rain or shine.

- Similes: as right as rain, as white as snow, like greased lightning (very quickly).

- Metaphors: hot-blooded/ cold-blooded, a ray of sunshine.

\section{CONCLUSIONS}

This paper aimed at illustrating the presence of culturally-marked items in the lexicon of a language through the analysis of the cultural and lexical domain of the weather in English. We hypothesize that the wealth of weather words, their pragmatic function and the 
productivity of the domain as a source of figurative language give evidence of its cultural salience.

Further research need to address this issue in a more systematic way. The scope of this study being limited, it seems that a deeper semantic analysis of cultural sets in a range of languages using larger corpora should be done.

\section{REFERENCES}

Boers, F. and H. Stengers. 2008. "Adding sound to the picture. Motivating the lexical composition of metaphorical idioms in English, Dutch and Spanish." Confronting Metaphor in Use. An Applied Linguistic Approach. Eds. M.S. Zanotto, L. Cameron and M.C. CavalcanTi. Amsterdam: John Benjamins. 63-78.

Dobrovol'skis, D. and E. Pirrainen. 2005. Figurative Language. cross-Cultural and Cross-Linguistic Perspectives. Amsterdam: Elsevier.

GiBBS, R.W., JR. and G. J. STEEN. 1999. Metaphor in Cognitive Linguistics. Amsterdam: John Benjamins.

InCHAURRALDE, C. 2003. "Marked communication and cultural knowledge in lexis." Text, Context, Concepts . Ed. C. Zelinsky-Wibbelt. Berlin: Mouton de Gruyter. 179-196.

KóveCSES, Z. 2000. Metaphor and Emotion. Language, Culture and Body in Human Feeling. Cambridge: Cambridge University Press.

2006. Language, Mind and Culture. A Practical Introduction. Oxford:

Oxford University Press.

LAKOFF, G. 2006. "The contemporary theory of metaphor." Cognitive Linguistics: Basic Readings. Ed. D. Geeraerts. Berlin: Mouton de Gruyter. 186-238.

Longman Dictionary of Contemporary English. 2009. London: Longman.

Mikes, G. 1970. How to be an Alien. Hardmondsworth: Penguin

MusolfF, A. 2004. Metaphor and Political Discourse. New York: Palgrave.

Oxford Dictionary of English Idioms. 1993. Oxford: Oxford University Press.

QuINN, N. 1991. "The cultural basis of metaphor." Beyond Metaphor. The Theory of Tropes in Anthropology. Ed. J.W. FERnANDEZ. Stanford: Stanford University Press. 56-93.

Quinn, N.and D. Holland. 1987. Preface. Cultural Models in Language and Thought.

Eds. D. Holland and N. Quinn. Cambridge: Cambridge University Press.

Wierzbicka, A. 1992. Semantics, Culture, and Cognition. Universal Human Concepts in Culture-Specific Configurations. Oxford: Oxford University Press. 1996. Semantics: Primes and Universals. Oxford: Oxford University

Press. 
1997. Understanding Cultures through their Key Words. Oxford: Oxford University Press.

1999. Emotions across Languages and Cultures: Diversity and Universals. Cambridge: Cambridge University Press.

2008. "A conceptual basis for intercultural pragmatics and world-wide understanding". Developing Contrastive Pragmatics. Eds. M. Pütz and J. NefF-VAN Aertselaer. Berlin: Mouton de Gruyter. 3-45. 